Conference Presentation

\title{
Action of methicillin on the "in vitro" growth of bacteria Staphyloccocus aureus methicillin-resistance previously treated with homeopathic dilutions
}

\author{
Tânia Aguiar Passeti, Leandro Ribeiro Bissoli, Registila Libania Beltrame e Fernando \\ Fonsceca
}

ABC Medical School of Santo André, Brazil.

Email: tania.passeti@japta.com.br

\begin{abstract}
Background: Methicillin-resistant Staphylococcus aureus (MRSA) causes nosocomial infections, and it has been considered as a worldwide epidemic. The medical system seeks new strategies to fight against MRSA that do not generate resistant strains to antibiotics. Homeopathy has been explored as one of these new strategies, which may play a pivotal role. In this context, we conducted studies on the action of homeopathy on growth of MRSA bacteria in vitro. The results showed a decrease in growth of bacterial strains with homeopathic dilutions of Belladonna and the $S$. aureus nosode. Now we have proposed to evaluate the minimum inhibitory concentration (MIC) of the antibiotic methicillin or oxacillin on $S$. aureus MRSA, previously incubated with the homeopathic dilutions of Belladonna or S. aureus nosode.

Methods: The Clinical and Laboratory Standards Institute (CLSI 2014) standards were followed according to the determination of the minimum inhibitory concentration (MIC). In $5 \mathrm{~mL}$ of cation adjusted Mueller Hinton (CAMH) broth, it was added $420 \mu \mathrm{l}$ of $30 \%$ alcohol or Belladonna and S. aureus' nosode in the dilutions $6 \mathrm{cH}, 12 \mathrm{cH}$ and $30 \mathrm{cH}$. Then a $20 \mu \mathrm{l}$ of bacterial suspension of MRSA was added to $0.5 \mathrm{McF}$ arland range and diluted to $1 / 10$. The tubes were incubated in an oven at $37^{\circ} \mathrm{C}$ for three hours. The plates were previously prepared with $50 \mu \mathrm{l}$ per well of serial dilutions of the antibiotic oxacillin in concentrations of $128 \mu \mathrm{g} / \mathrm{mL}$ to $0.5 \mu \mathrm{g} / \mathrm{mL}$ in CAMH broth. Then it was added $50 \mu \mathrm{l}$ per well of bacterial cultures. The plate was incubated in an oven at $37^{\circ} \mathrm{C}$ for 24 hours and the bacterial growth measured in a spectrophotometer $600 \mathrm{~nm}$. The point of the MIC of oxacillin for S. aureus is $4 \mu \mathrm{g} / \mathrm{mL}$, according to CLSI 2014 criteria.
\end{abstract}

Results: We did not observe the total inhibition of bacterial growth when incubated with the homeopathic medicine and oxacillin. In evaluation of the spectrophotometer culture, we observed significant changes in the growth, compared to the control (30\% alcohol). Cultures treated with Belladonna $6 \mathrm{cH}$ and the antibiotic in the dilution $4 \mu \mathrm{g} / \mathrm{mL}$ showed a decrease of $40 \%$ of the growth, while in the $30 \mathrm{cH}$ the drop was of $75 \%$. Cultures treated with the $S$. aureus nosode $30 \mathrm{cH}$ and the antibiotic at $4 \mu \mathrm{g} / \mathrm{mL}$ dilution, showed a decrease of $60 \%$ in bacterial growth in vitro.

OPEN ACCESS

Cite as: Passeti TA, Bissoli LR, Fonsceca RLBF. Action of methicillin on the growth "in vitro" of bacteria Staphyloccocus aureus methicillin-resistance previously homeopathic treatment. Proceedings of the XXIX GIRI Meeting; 2015 June 3 - 5; Verona (Italy). Int J High Dilution Res. 2015; 14(2): 57-58 
Conclusion: The results suggest that bacterial cultures the $S$. aureus (MRSA) incubated with the homeopathic medicines would be more susceptible to oxacillin's antimicrobial action.

Keywords: homeopathic medicines, Staphylococcus aureus, MRSA, in vitro, high dilution, belladonna

(C) International Journal of High Dilution Research.

Not for commercial purposes.

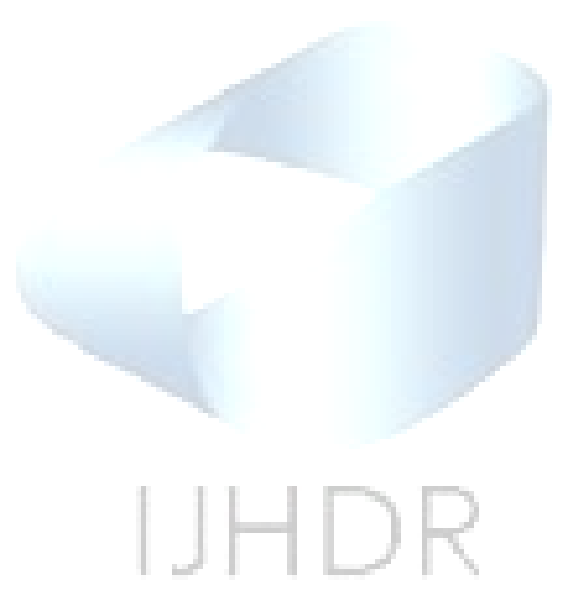

OPEN ACCESS

Cite as: Passeti TA, Bissoli LR, Fonsceca RLBF. Action of methicillin on the growth "in vitro" of bacteria Staphyloccocus aureus methicillin-resistance previously homeopathic treatment. Proceedings of the XXIX GIRI Meeting; 2015 June 3 - 5;

Verona (Italy). Int J High Dilution Res. 2015; 14(2): 57-58 